\title{
Zróżnicowanie wyleczalności chorych na wybrane nowotwory złośliwe w Polsce na tle krajów europejskich w latach 2005-2009 na podstawie badania CONCORD 2
}

\author{
Magdalena Bielska-Lasota' ${ }^{1}$ Michalina Krzyżak², Katarzyna Kwiatkowska', \\ Joanna Bogusz ${ }^{1}$, Dominik Maślach ${ }^{2}$, Mirosław J. Wysocki ${ }^{1}$
}

\begin{abstract}
Wstęp. Wskaźniki 5-letnich przeżyć populacyjnych obrazują poziom wyleczalności nowotworów złośliwych w populacji, a zatem są jednym z najważniejszych narzędzi do oceny efektywności walki z rakiem. Dzięki ujednoliconej metodologii ogólnoświatowego badania CONCORD 2 wskaźniki obliczone dla Polski można było porównać z innymi krajami Europy. Celem opracowania była ocena wyleczalności chorych na wybrane nowotwory w Polsce oraz w niektórych województwach na tle krajów europejskich.

Materiałi metody. W analizach własnych wykorzystano wyniki badania CONCORD 2 obliczone na podstawie danych zgromadzonych przez populacyjne rejestry nowotworów chorych, u których rozpoznano nowotwór złośliwy w latach 2005-2009 i obserwowanych do końca 2009 roku. Z wyników wyodrębniono dane dotyczące Polski udostępnione dla celów CONCORD 2 przez Krajowy Rejestr Nowotworów oraz Wojewódzkie Biura Rejestracji Nowotworów w województwach: dolnośląskim, podkarpackim, świętokrzyskim i wielkopolskim. Wskaźniki 5-letnich przeżyć obliczono metodą estymacji Pohar Perme net survival.

Wyniki. W Polsce u chorych na raka gruczołu krokowego (74\%), piersi (74\%), szyjki macicy (53\%), okrężnicy (50\%), odbytnicy (47\%), jajnika (34\%) i żołądka (19\%) wskaźniki 5-letnich przeżyć należały do najniższych w Europie. Natomiast u chorych na białaczki (49\%) i raka płuca (13\%) przeżycia były na poziomie przeciętnych w Europie. Analiza według województw wykazała zróżnicowanie regionalne. Największe różnice dotyczyły białaczek w województwach dolnośląskim i świętokrzyskim (14\%), raka gruczołu krokowego w wielkopolskim i świętokrzyskim (10\%) oraz raka piersi w wielkopolskim i podkarpackim (6\%), co wskazuje na zróżnicowanie w standardach profilaktyki i leczenia.

Wnioski. Badanie wykazało zróżnicowanie wskaźnika 5-letnich przeżyć w Europie na niekorzyść Polski. W nowotworach dobrze rokujących takich jak: rak gruczołu krokowego, piersi, okrężnicy i odbytnicy wskaźniki należały do najniższych w Europie, natomiast u chorych na raka płuca oraz białaczki były na poziomie przeciętnych w Europie.
\end{abstract}

\section{Differences in treatment outcomes in selected cancers in Poland compared to other European countries in 2005-2009, based on CONCORD 2 study}

Background. The 5-year net survival rates show the outcomes of cancer treatment in population, therefore, they are one of the most important measures used to evaluate the effectiveness of cancer treatment. The standardized methodology in CONCORD 2 study of global cancer survival allows to compare the net survival in Poland with other European countries. The aim of this article was to assess the treatment in selected cancers in Poland and selected Polish voivodships in comparison to other European countries.

Methods. In our analyses the CONCORD 2 results, based on the data from population-based Cancer Registries for patients diagnosed: 2005-2009 and followed up to 2009, were used. The results regarding Poland included the data previously provided by the National Cancer Registry and four Regional Cancer Registries: Greater Poland, Świętokrzyskie, Lower Silesia and Podkarpackie. The Pohar Perme's method called net survival was used to calculate the 5-year survival.

\footnotetext{
${ }^{1}$ Narodowy Instytut Zdrowia Publicznego — Państwowy Zakład Higieny, Warszawa

${ }^{2}$ Zakład Zdrowia Publicznego, Uniwersytet Medyczny w Białymstoku
} 
Results. The 5-year net survival in Poland was the lowest in Europe for patients diagnosed with prostate (74\%), breast $(74 \%)$, colon $(50 \%)$, rectum $(47 \%)$, stomach $(19 \%)$, ovary $(34 \%)$, cervical $(53 \%)$ cancers. However, the survival for patients diagnosed with leukemias (49\%) and lung cancer (13\%) was on the average European level. The analysis of voivodships' data proved the differences in the regions. The highest differences were for patients with leukemias in Lower Silesia and Świętokrzyskie (14\%), prostate cancer in Greater Poland and Świętokrzyskie (10\%), breast cancer in Greater Poland and Podkarpackie (6\%), which showed differences in prevention and treatment standards.

Conclusions. The study showed the differences in 5-year net survival rates in Europe, which were unfavourable for Poland. Cancers that have good prognosis such as: prostate, breast, colon and rectum had the lowest survival rates in Europe, however, patients with lung cancer and leukemias were on the average European level.

NOWOTWORY J Oncol 2016; 66, 3: 202-211

Słowa kluczowe: nowotwory złośliwe, wskaźnik 5-letnich przeżyć, CONCORD 2

Keys words: cancer, 5-year net survival, CONCORD 2

\section{Wstęp}

Rosnące obciążenie chorobami nowotworowymi w krajach europejskich nabiera coraz większego znaczenia w aspekcie zdrowotnym, społecznym, a także finansowym. Przewiduje się, że w Europie problem ten będzie narastał, co wiąże się z procesem starzenia się populacji oraz zwiększonego narażenia na czynniki ryzyka.

W związku z tymi prognozami Światowa Organizacja Zdrowia oraz UICC (Union for International Cancer Control) zalecają podjęcie planowych działań w kierunku zwiększenia efektywności dotychczasowej walki z rakiem, takich jak: upowszechnianie profilaktyki pierwotnej i wtórnej, systematyczne wdrażanie nowoczesnych technologii w diagnostyce, poprawa dostępności do optymalnego leczenia i rehabilitacji. Systematyczne działania wymagają długoterminowej alokacji środków finansowanych [1, 2].

Niezbędnym narzędziem w realizacji tych celów jest ocena efektów zdrowotnych podjętych działań, dokonywana z zastosowaniem metod naukowych (public health evidence based). Populacyjny wskaźnik 5-letnich przeżyć, obok liczby oraz współczynników zachorowalności i umieralności, jest jednym z najważniejszych mierników umożliwiających tę ocenę, co znalazło odzwierciedlenie w strategiach zwalczania raka w wielu krajach europejskich, m.in. w strategii opracowanej dla Wielkiej Brytanii [3].

Dotychczas w Polsce populacyjne wskaźniki 5-letnich przeżyć były rzadko publikowane. Wśród ostatnich jest m.in. opracowanie na podstawie danych Krajowego Rejestru Nowotworów (KRN) dotyczące przeżyć chorych, u których nowotwór rozpoznano w latach 2003-2005, oraz nieliczne opracowania na podstawie regionalnych rejestrów nowotworów, obecnie Wojewódzkich Biur Rejestracji Nowotworów (WBRN) [4-6].

Populacyjne wskaźniki przeżyć w krajach europejskich zostały opublikowane $\mathrm{w}$ ramach pięciu edycji projektu EUROCARE. Ostatnie publikacje oparte na danych o zachorowaniach w latach 1999-2007 w Krakowie oraz wojewódz- twach dolnośląskim i świętokrzyskim obejmowały około 25\% populacji Polski [7].

Dostrzegając potrzebę systematycznej obserwacji postępu w wyleczalności chorób nowotworowych, międzynarodowa grupa badawcza CONCORD podjęła inicjatywę wdrożenia systemu monitorowania populacyjnego wskaźnika 5-letnich przeżyć na pięciu kontynentach świata [8]. Celem CONCORD było zgromadzenie danych pochodzących z populacyjnych rejestrów nowotworów o zasięgu krajowym oraz regionalnym, kontrola jakości danych, a następnie przeprowadzenie analiz w sposób umożliwiający porównania pomiędzy krajami oraz obserwację zmian w czasie, wreszcie szerokie upowszechnienie wyników w publikacjach o zasięgu światowym.

Celem niniejszego opracowania była ocena wskaźników 5-letnich przeżyć w Polsce oraz w wybranych województwach kraju na tle 27 krajów europejskich na podstawie opublikowanych wyników CONCORD 2.

\section{Metoda}

Dla potrzeb niniejszego opracowania z opublikowanych wyników CONCORD 2 wyodrębniono informacje dotyczące całej populacji Polski oraz osobno województw: dolnośląskiego (11\%), wielkopolskiego (9\%), podkarpackiego (5\%) i świętokrzyskiego (5\%). Dane z Polski obejmujące populację całego kraju pochodziły ze zbioru KRN, a dane regionalne zostały opracowane przez WBRN niezależnie od zbioru krajowego.

Wyodrębniono także informacje pochodzące z krajów Unii Europejskiej oraz Islandii, Norwegii i Szwajcarii, co stanowiło podstawę do dalszych porównań. Dane z krajów europejskich pochodziły z rejestrów populacyjnych o zasięgu krajowym (Austria, Belgia, Bułgaria, Chorwacja, Czechy, Dania, Estonia, Finlandia, Islandia, Irlandia, Holandia, Litwa, Łotwa, Malta, Norwegia, Portugalia, Słowacja, Słowenia, Szwecja) oraz regionalnym, tj. ograniczonym do ściśle określonego obszaru administracyjnego objętego rejestracją nowotworów: Szwajcaria (47\% populacji kraju), 
Niemcy (43\%), Włochy (39\%), Hiszpania (22\%), Francja (18\%) oraz Rumunia (3\%), którą pominięto w dyskusji ze względu na niską reprezentatywność kraju.

Analiza przeżyć w ramach CONCORD 2 obejmowała chorych w wieku od 15 roku życia, którzy w latach 1995-2009 zachorowali na jedną z dziesięciu chorób nowotworowych najczęściej występujących na świecie. Choroby te są objęte klasyfikacją ICD-O-3, z uwzględnieniem lokalizacji narządowej oraz budowy histopatologicznej nowotworu [9].

Populacyjne wskaźniki 5-letnich przeżyć zostały obliczone metodą estymacji Pohar Perme net survival [10]. Metoda ta uwzględnia tylko przypadki, w których przyczyną zgonu był nowotwór złośliwy. Chorzy na nowotwory, którzy zmarli z innej przyczyny, byli wykluczeni na podstawie tzw. oczekiwanej umieralności (background mortality). Estymator net survival uwzględnia również fakt, że ryzyko zgonu z powodów innych niż nowotwór u osób w starszym wieku jest wyższe niż u osób młodych. Analizy przeprowadzono u chorych obu płci razem z wyjątkiem chorych na raka piersi, które ograniczono tylko do kobiet. Wskaźniki net survival zostały obliczone $z$ wykorzystaniem regionalnych tabel trwania życia.

W niniejszym opracowaniu analizie poddano wskaźniki 5-letnich przeżyć u chorych, którzy w latach 2005-2009 zachorowali na raka: żołądka, okrężnicy, odbytnicy, płuca, piersi, szyjki macicy, jajnika, gruczołu krokowego oraz na białaczki, wymienione w tabeli I (zgodnie z kodem ICD-O-3).

Dla ułatwienia interpretacji wyników wyodrębniono kraje, które w omawianym okresie należały do nowo przyjętych w Unii Europejskiej. Z wyjątkiem Malty były to kraje o podobnej przeszłości politycznej i gospodarczej i zostały omówione w jednej grupie, jako kraje „Europy Wschodniej”. Dla pozostałych krajów stosowano tradycyjną nazwę „Europa Zachodnia".

\section{Jakość danych}

Zgodnie z metodologią CONCORD w centrum analitycznym w London School of Hygiene and Tropical Medicine każdy ze zbiorów poddano proceduralnej kontroli jakości pod względem zgodności oraz spójności wewnętrznej.
Prace prowadzono w ścisłej współpracy z Rejestrami Nowotworów, które dane te dostarczyły. Wskaźniki jakości przedstawiono $w$ tabeli II.

Z analizy przeżyć zostały wyłączone przypadki: stracone z obserwacji, z niepotwierdzonym rozpoznaniem nowotworu złośliwego w dalszej obserwacji, z niespecyficzną morfologią oraz obserwowane krócej niż jedną dobę (DCO - death certificate only).

Dane polskie charakteryzowała wysoka jakość. Odsetek przypadków wyłączonych z analizy przeżyć wynosił od poniżej 1\% w raku odbytnicy i w białaczkach do 7,9\% w raku żołądka i w większości nowotworów był niższy niż w innych krajach europejskich. Natomiast w Polsce zwraca uwagę niski odsetek potwierdzeń mikroskopowych, który z wyjątkiem białaczek był niższy i znacznie niższy niż w krajach europejskich, co jest odzwierciedleniem istotnych problemów związanych z diagnostyką histopatologiczną w Polsce.

\section{Wyniki}

Na rycinie 1 przedstawiono wskaźniki 5-letnich przeżyć w zależności od jednostki chorobowej określonej zgodnie z klasyfikacją ICD-O-3 oraz według kraju zamieszkania chorego.

Najlepsze rokowanie było u chorych na raka gruczołu krokowego i piersi. W czternastu krajach Europy Zachodniej oraz na Litwie u chorych na raka gruczołu krokowego wskaźnik 5-letnich przeżyć wynosił ponad 85\% i sięgał 93\% w Finlandii i Belgii. Najniższe przeżycia były na Słowacji (66\%) i w Bułgarii (53\%).

U chorych na raka piersi przeżycia były mniej zróżnicowane i we wszystkich krajach Europy Zachodniej (z wyjątkiem Malty) oraz w Słowenii i w Czechach wskaźnik przekraczał 80\%, zaś we Francji i w Finlandii 87\%. Na Litwie, Łotwie i w Estonii oraz na Słowacji wskaźniki były najniższe, lecz kształtowały się na wyższym poziomie aniżeli najniższe w Europie Wschodniej na Słowacji i w Bułgarii u chorych na raka gruczołu krokowego. W Polsce w obu tych chorobach nowotworowych wskaźnik $74 \%$ plasował nasz kraj wśród niskich w Europie Zachodniej i przeciętnych w Europie Wschodniej.

Tabela I. Białaczki u dorosłych włączone do badania CONCORD 2

\begin{tabular}{ll}
\hline Nazwa białaczki & Kod morfologiczny wg klasyfikacji ICD-0-3 \\
\hline Przewlekła białaczka limfocytowa i chłoniak z małych limfocytów & $9670 ; 9823$ \\
Białaczka/chłoniak z komórek Burkitta & $9687 ; 9826$ \\
Białaczka limfoblastyczna z komórek prekursorowych i chłoniak & $9727 ; 9728 ; 9729 ; 9835 ; 9836 ; 9837$ \\
limfoblastyczny z komórek prekursorowych & \\
Białaczka z komórek B & 9833 \\
Białaczka z komórek B, włochatokomórkowa & 9940 \\
Białaczka limfatyczna, nieokreślona & $9820 ; 9832$ \\
Białaczka nieokreślona & $9800 ; 9801 ; 9805$ \\
\hline
\end{tabular}




\begin{tabular}{|c|c|c|c|c|c|}
\hline & \multirow{2}{*}{$\begin{array}{l}\text { Liczba przypadków } \\
\text { włączonych do analizy } \\
\text { przeżyć }\end{array}$} & \multirow{2}{*}{$\begin{array}{c}\text { Potwierdzone } \\
\text { mikroskopowo (\%) }\end{array}$} & \multicolumn{3}{|c|}{ Wykluczenia } \\
\hline & & & $\begin{array}{c}\text { DCO* i inne } \\
\text { wykluczenia (\%) }\end{array}$ & $\begin{array}{c}\text { Stracone z obserwacji } \\
\text { i niepotwierdzone }{ }^{* *}(\%)\end{array}$ & $\begin{array}{l}\text { Ogółem } \\
\text { (\%) }\end{array}$ \\
\hline \multicolumn{6}{|c|}{ Żołądek (C16) } \\
\hline Polska & 60115 & 73,6 & 7,9 & 0,1 & 7,9 \\
\hline Europa & 621585 & 89,7 & 7,7 & 0,4 & 7,7 \\
\hline \multicolumn{6}{|c|}{ Okrężnica (C18-C19) } \\
\hline Polska & 93762 & 78,8 & 4,8 & 0,1 & 5,0 \\
\hline Europa & 1487141 & 91,7 & 5,0 & 0,6 & 5,0 \\
\hline \multicolumn{6}{|c|}{ Odbytnica (C20-C21) } \\
\hline Polska & 60178 & 85,1 & 3,1 & 0,1 & 3,2 \\
\hline Europa & 691181 & 94,3 & 4,0 & 0,6 & 4,0 \\
\hline \multicolumn{6}{|l|}{ Płuco (C34) } \\
\hline Polska & 225554 & 72,2 & 5,3 & 0,1 & 5,3 \\
\hline Europa & 1983228 & 79,6 & 6,9 & 0,3 & 6,9 \\
\hline \multicolumn{6}{|l|}{ Pierś (C50) } \\
\hline Polska & 151046 & 91,3 & 1,8 & 0,1 & 1,8 \\
\hline Europa & 2281321 & 95,3 & $<2,1$ & 1,1 & 2,1 \\
\hline \multicolumn{6}{|c|}{ Szyjka macicy (C53) } \\
\hline Polska & 39367 & 90,8 & 1,6 & 0,1 & 1,7 \\
\hline Europa & 245190 & 95,9 & 2,2 & 1,0 & 2,2 \\
\hline \multicolumn{6}{|l|}{ Jajnik (C56) } \\
\hline Polska & 39430 & 79,3 & 3,8 & 0,1 & 3,8 \\
\hline Europa & 373542 & 88,9 & 5,4 & 0,5 & 5,4 \\
\hline \multicolumn{6}{|c|}{ Gruczoł krokowy (C61) } \\
\hline Polska & 79083 & 80,2 & 4,6 & 0,1 & 4,6 \\
\hline Europa & 1836205 & 92,3 & 3,3 & 1,1 & 3,2 \\
\hline \multicolumn{6}{|c|}{ Białaczki u dorosłych (C91-C95) } \\
\hline Polska & 2630 & 100,0 & 0,0 & 0,1 & 0,0 \\
\hline Europa & 330922 & 92,4 & $<5,4$ & 0,8 & 5,4 \\
\hline
\end{tabular}

U chorych na raka szyjki macicy rokowanie było gorsze. W dwunastu krajach Europy Zachodniej oraz w Rumunii, Słowenii, Estonii, Chorwacji i Czechach wskaźnik wynosił 65\% lub był wyższy; najwyższy był w Norwegii i Islandii, gdzie wynosił $73 \%$. Najniższy wskaźnik, poniżej $60 \%$, był we Francji i w Irlandii oraz w czterech krajach Europy Wschodniej. W Polsce i w Bułgarii wskaźnik 53\% był najniższy spośród krajów europejskich.

Jeszcze mniej korzystne i bardziej zróżnicowane były przeżycia chorych na raka jelita grubego. Wskaźnik 60\% i wyższy był u chorych na raka okrężnicy w dwunastu krajach Europy Zachodniej i tylko w dziesięciu u chorych na raka odbytnicy. Najwyższe wskaźniki były w Islandii i w Belgii, a także w Niemczech i w Norwegii. W krajach Europy Wschodniej, z wyjątkiem Słowenii i Czech, wskaźniki były znacznie niższe. W Polsce u chorych na raka okrężnicy wskaźnik wynosił $50 \%$ oraz $47 \%$ u chorych na raka odbytnicy i był korzystniejszy tylko w porównaniu ze Słowacją, Bułgarią i Łotwą.

Wyleczalność chorych na białaczki w dwunastu krajach Europy Zachodniej oraz na Łotwie wynosiła ponad 50\% i sięgała prawie $60 \%$ w Belgii, Szwecji i we Francji. Najniższe wskaźniki były w Bułgarii i na Malcie. W Polsce wskaźnik wynosił 49\% i nie odbiegał od przeciętnych w Europie.

Rak płuca był nadal nowotworem o bardzo złym rokowaniu, ze wskaźnikiem 5-letnich przeżyć około 15\% najwyższym w Austrii, Belgii i Szwajcarii. Wskaźnik 5-letnich przeżyć w Polsce wynosił $13 \%$.

Nieco lepsze było rokowanie u chorych na raka żołądka w Polsce 19\%, a w niektórych krajach wskaźnik wyleczalności przekraczał 30\%; najwyższy był w Austrii, Belgii i Portugalii.

Także wyleczalność chorych na raka jajnika była stosunkowo niska, i w siedmiu krajach Europy Zachodniej wskaźnik wynosił 40\% lub nieznacznie więcej; najlepsze przeżycia były w Finlandii, Szwecji i Belgii. W krajach Europy Wschodniej (z wyjątkiem Rumunii) były znacznie niższe. W Polsce wskaźnik u chorych na raka jajnika wynosił $34 \%$.

Regionalne zróżnicowanie wyleczalności stwierdzono także na terenie Polski. W tabeli III przedstawiono zróżnicowanie pomiędzy województwami uczestniczącymi w badaniu CONCORD 2.

W województwie wielkopolskim u chorych na raka gruczołu krokowego, a także żołądka, okrężnicy i odbytnicy 


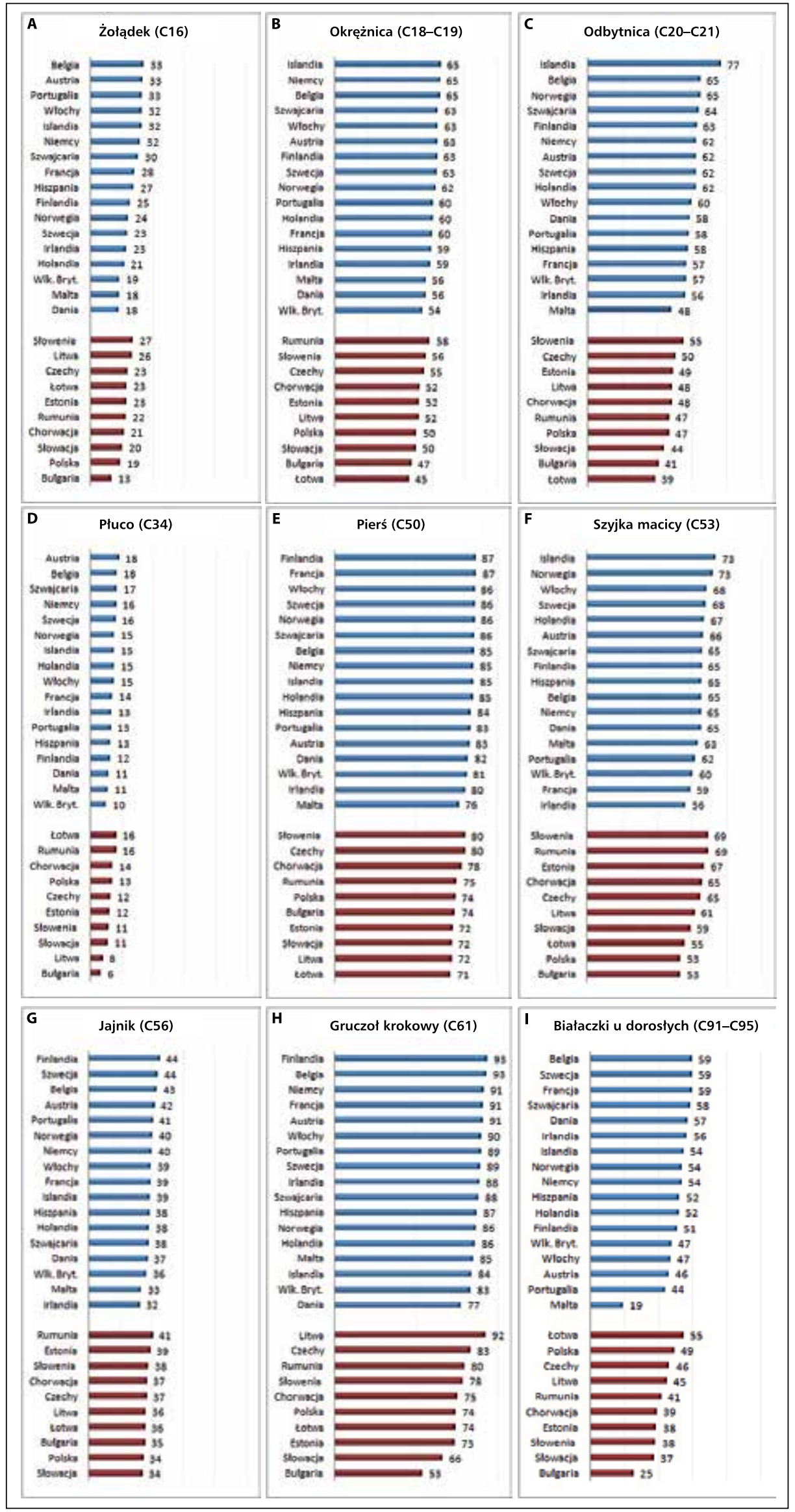

Rycina 1A-I. Wskaźniki 5-letnich przeżyć (\%) chorych na wybrane nowotwory złośliwe w krajach europejskich. Lata 2005-2009 
Tabela III. Wskaźniki 5-letnich przeżyć populacyjnych w wybranych województwach Polski w latach 2005-2009

\begin{tabular}{|c|c|c|c|}
\hline & Liczba zachorowań* & Wskaźnik 5-letnich przeżyć** & 95\% przedział ufności \\
\hline \multicolumn{4}{|l|}{ Żoładek (C16) } \\
\hline woj. dolnośląskie & 7103 & 16,2 & $14,4-18,0$ \\
\hline woj. podkarpackie & 3514 & 16,0 & $14,1-18,0$ \\
\hline woj. świętokrzyskie & 3186 & 15,4 & $12,9-17,9$ \\
\hline woj. wielkopolskie & 4755 & 19,6 & $17,5-21,8$ \\
\hline Polska & 60115 & 18,6 & $18,0-19,2$ \\
\hline \multicolumn{4}{|l|}{ Okrężnica (C18-C19) } \\
\hline woj. dolnośląskie & 10466 & 49,2 & $47,0-51,4$ \\
\hline woj. podkarpackie & 4185 & 47,2 & $44,5-49,8$ \\
\hline woj. świętokrzyskie & 3964 & 48,8 & $45,7-51,9$ \\
\hline woj. wielkopolskie & 8235 & 49,8 & $47,7-51,8$ \\
\hline Polska & 93762 & 50,1 & $49,5-50,7$ \\
\hline \multicolumn{4}{|l|}{ Odbytnica (C20-C21) } \\
\hline woj. dolnośląskie & 6909 & 46,9 & $44,4-49,5$ \\
\hline woj. podkarpackie & 3127 & 46,0 & $42,8-49,3$ \\
\hline woj. świętokrzyskie & 2875 & 46,3 & $42,6-50,0$ \\
\hline woj. wielkopolskie & 5188 & 49,5 & $47,0-52,2$ \\
\hline Polska & 60178 & 46,9 & $46,1-47,6$ \\
\hline \multicolumn{4}{|l|}{ Płuco (C34) } \\
\hline woj. dolnośląskie & 28053 & 15,0 & $14,1-15,9$ \\
\hline woj. podkarpackie & 10238 & 14,0 & $12,8-15,2$ \\
\hline woj. świętokrzyskie & 10458 & 11,1 & $9,9-12,4$ \\
\hline woj. wielkopolskie & 17113 & 13,2 & $12,1-14,3$ \\
\hline Polska & 225554 & 13,4 & $13,1-13,7$ \\
\hline \multicolumn{4}{|l|}{ Pierś (C50) } \\
\hline woj. dolnośląskie & 15948 & 75,4 & $73,4-77,4$ \\
\hline woj. podkarpackie & 5996 & 68,2 & $65,3-71,0$ \\
\hline woj. świętokrzyskie & 5778 & 69,3 & $66,3-72,3$ \\
\hline woj. wielkopolskie & 13996 & 74,6 & $72,6-76,6$ \\
\hline Polska & 151046 & 74,1 & $73,5-74,7$ \\
\hline \multicolumn{4}{|l|}{ Szyjka macicy (C53) } \\
\hline woj. dolnoślaskie & 4383 & 51,7 & $48,9-54,6$ \\
\hline woj. podkarpackie & 1737 & 56,4 & $52,6-60,2$ \\
\hline woj. świętokrzyskie & 1797 & 56,6 & $52,4-60,9$ \\
\hline woj. wielkopolskie & 2917 & 53,8 & $50,7-57,0$ \\
\hline Polska & 39367 & 53,0 & $52,1-53,9$ \\
\hline \multicolumn{4}{|l|}{ Jajnik (C56) } \\
\hline woj. dolnośląskie & 4200 & 33,1 & $30,4-35,7$ \\
\hline woj. podkarpackie & 1958 & 34,0 & $30,5-37,4$ \\
\hline woj. świętokrzyskie & 1609 & 37,2 & $32,6-41,7$ \\
\hline woj. wielkopolskie & 3285 & 35,2 & $32,2-38,3$ \\
\hline Polska & 39430 & 34,3 & $33,5-35,2$ \\
\hline \multicolumn{4}{|l|}{ Gruczoł krokowy (C61) } \\
\hline woj. dolnośląskie & 7135 & 70,1 & $67,4-72,9$ \\
\hline woj. podkarpackie & 4350 & 69,0 & $65,9-72,2$ \\
\hline woj. świętokrzyskie & 3968 & 66,5 & $62,7-70,3$ \\
\hline woj. wielkopolskie & 7254 & 76,5 & $73,4-79,2$ \\
\hline Polska & 79083 & 74,1 & $73,4-74,9$ \\
\hline \multicolumn{4}{|c|}{ Białaczki u dorosłych (C91-C95) } \\
\hline woj. dolnoślaskie & 1008 & 56,5 & $49,8-63,2$ \\
\hline woj. podkarpackie & bd.* & $b d^{* *}$ & $b d^{* *}$ \\
\hline woj. świętokrzyskie & 1622 & 42,3 & $37,7-46,9$ \\
\hline woj. wielkopolskie & bd.* & $b^{* * *}$ & $b d^{* *}$ \\
\hline Polska & 2630 & 49,0 & $45,2-52,7$ \\
\hline
\end{tabular}

*w latach 1995-2009

**w latach 2005-2009

wskaźnik 5-letnich przeżyć był znacząco wyższy niż w innych województwach. Także w porównaniu z Polską ogółem wskaźnik w województwie wielkopolskim był nieco wyższy u chorych na raka gruczołu krokowego, żołądka i odbytnicy.
W województwie dolnośląskim najwyższe, a także wyższe niż w kraju były wskaźniki u chorych na raka piersi oraz białaczki. 
Wskaźniki 5-letnich przeżyć chorych na raka szyjki macicy najwyższe były w województwach świętokrzyskim i podkarpackim i znacznie wyższe w porównaniu z województwem wielkopolskim i dolnośląskim, a także w Polsce ogółem.

\section{Dyskusja}

Już ponad 50 lat temu wskaźniki 5-letnich przeżyć populacyjnych znalazły zastosowanie w ocenie wyleczalności chorych na nowotwory złośliwe [11, 12]. W Polsce pierwszej takiej oceny dotyczącej mieszkańców Warszawy i wybranych terenów wiejskich w latach 1963-1972 dokonał prof. Tadeusz Koszarowski z zespołem, który wykazał, że istnieje znaczące zróżnicowanie wskaźników przeżyć na niekorzyść terenów wiejskich [13].

We wczesnym okresie znaczące rozbieżności w metodologii prowadzenia badań w różnych krajach, głównie w zakresie sposobu gromadzenia danych, a także obliczania wskaźników i ich standaryzacji utrudniały prowadzenie badań porównawczych. W zainicjowanym w 1978 roku badaniu EUROCARE, a następnie w badaniu CONCORD ujednolicono metodologię gromadzenia danych, wprowadzono jednorodną kontrolę jakości oraz scentralizowano prowadzenie analiz [14, 15]. Dzięki tym rozwiązaniom wyniki EUROCARE 3, obejmujące zachorowania w latach 1990-94, obrazowały już rzeczywiste zróżnicowanie wyleczalności nowotworów w Europie. Wskaźniki były szczególnie niekorzystne w krajach Europy Wschodniej i dotyczyło to przede wszystkim chorych na nowotwory, w których dokonywał się istotny postęp w zakresie rozpoznawania i leczenia.

Prezentowane wyniki CONCORD 2 potwierdziły wcześniejsze obserwacje, że w krajach europejskich rokowanie zależało przede wszystkim od jednostki chorobowej i było najkorzystniejsze u chorych na raka gruczołu krokowego i piersi, gorsze w raku szyjki macicy, jelita grubego i w białaczkach i nadal złe w raku płuca, żołądka i jajnika. Wśród nowotworów najlepiej rokujących najmniejsze różnice wyleczalności w Europie były u chorych na raka piersi, znacznie większe w raku gruczołu krokowego, odbytnicy oraz białaczkach.

Wyniki CONCORD 2 także potwierdziły wcześniejsze obserwacje, że w obecnym stuleciu dokonuje się istotny postęp w wyleczalności chorób nowotworowych w krajach, w których są dobrze rozwinięte systemy ochrony zdrowia $[15,16]$. Spośród dziesięciu najczęściej występujących nowotworów na świecie opracowanych w ramach CONCORD 2 największy wzrost bezwzględnej wartości wskaźnika w latach 1999-2007 dotyczył raka gruczołu krokowego (8,3\%), odbytnicy (5,5\%) i piersi (4,0\%) [17]. Obserwowane korzystne zmiany wiążą się przede wszystkim z wprowadzeniem na rynek leków nowej generacji, szerokim stosowaniem nowych technik operacyjnych (resekcja pozaotrzewnowa w raku odbytnicy) oraz coraz szerszym dostępem do skriningów populacyjnych wysokiej jakości [18].

Zmiany zachodzące w krajach Europy Wschodniej były większe niż średnio w Europie i wynosiły: 17,8\% u chorych na raka gruczołu krokowego, 7,1\% raka odbytnicy i 5,2\% raka piersi. W Polsce w latach 2000-2009 różnice wartości wskaźnika były jeszcze większe i wynosiły 19,8\% u chorych na raka gruczołu krokowego, $10,2 \%$ odbytnicy i $7,2 \%$ piersi. W Polsce pomimo tych korzystnych zmian wskaźniki 5-letnich przeżyć, szczególnie w nowotworach poddających się leczeniu, z wyjątkiem białaczek, pozostawały znacząco niższe niż w Europie Zachodniej.

Przyczyny utrzymującego się zróżnicowania przeżyć w krajach europejskich budzą wiele kontrowersji, głównie w środowiskach lekarskich i decydenckich, toteż podjęto dalsze szczególowe badania oparte na danych klinicznych typu High Resolution, które dostarczają kolejnych dowodów, że proporcja pacjentów we wczesnym stopniu zaawansowania choroby nowotworowej oraz dostępność leczenia uznanego za optymalne ma największe znaczenie w kształtowaniu wskaźników 5-letnich przeżyć w populacji [19-21]. Wiedza ta ma fundamentalne znaczenie dla określania potrzeb i budowania strategii walki z rakiem oraz w ocenie jej efektywności zdrowotnej. [19, 20, 22-25].

W świetle tych badań bardziej jest zrozumiałe zróżnicowanie wyleczalności dotyczące przede wszystkim nowotworów wykrywanych w skriningach populacyjnych, które w niektórych krajach Europy Zachodniej co najmniej od lat 90. są realizowane zgodnie ze standardem jakości określonym przez Komisję Europejską. Korzystny wpływ skriningu wiąże się ze wzrostem proporcji wczesnych rozpoznań u chorych w młodszych grupach wieku, co umożliwia wczesne podjęcie optymalnego leczenia i istotnie przyczynia się do poprawy rokowania [26-29].

Programy przesiewowe w krajach Europy Wschodniej rozpoczęto znacznie później [26]. W Polsce programy skriningowe o zasięgu krajowym realizowane są od 2006 roku i zgodnie z rekomendacjami Międzynarodowej Agencji Badań nad Rakiem (IARC) obejmują wczesne wykrywanie raka piersi i szyjki macicy oraz w mniejszej skali raka jelita grubego (tylko z zastosowaniem kolonoskopii) [27-31]. Pomimo znacznych nakładów finansowych ponoszonych na realizację skriningów w ramach Narodowego Programu Zwalczania Chorób Nowotworowych ich efekty zdrowotne nie zostały dotychczas ocenione, a wskaźniki przeżyć w latach 2005-2009 pozostawały na niskim poziomie [32].

Opóźnienie optymalnego leczenia jest niezależnym czynnikiem rokowniczym, ponieważ sprzyja progresji choroby. Opóźnienie ze strony systemu lecznictwa, w tym kolejki, są wyrazem niedostosowania zasobów do potrzeb wynikających z sytuacji epidemiologicznej i zwykle są skutkiem 


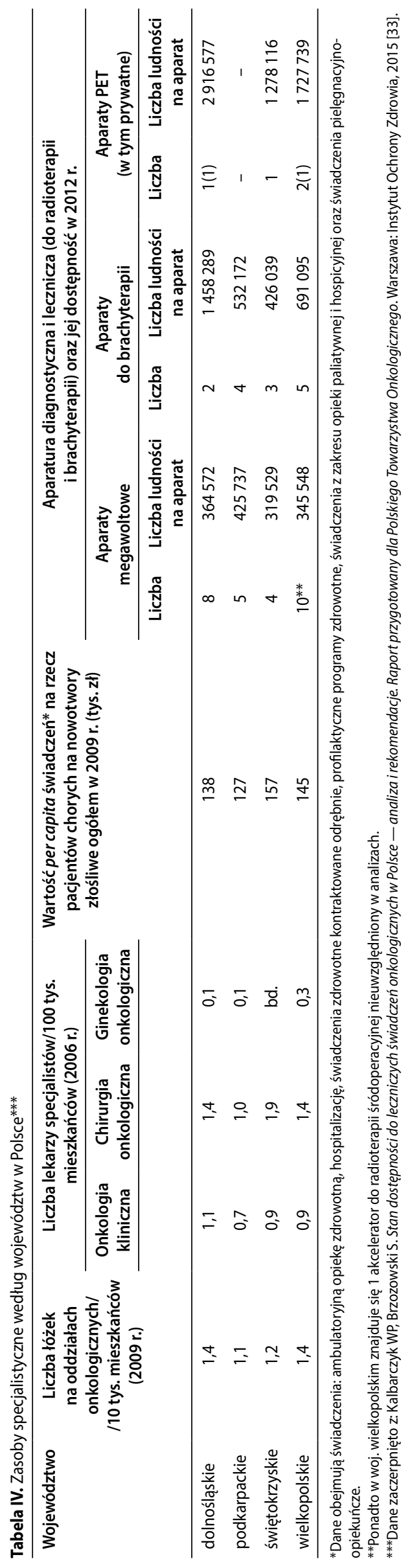

niesprawności organizacyjnej systemu, nierównomiernego rozmieszczenia kadr, zwłaszcza lekarzy i pielęgniarek, niewystarczającego wyposażenia w sprzęt i aparaturę do diagnostyki oraz do radioterapii, co przedstawiono w tabeli IV [24].Trudności w diagnostyce oraz niedobory kadrowe mają odbicie w niskim odsetku potwierdzeń mikroskopowych (tab. II). Na mapie Polski ważną przyczyną opóźnienia leczenia jest ograniczony dostęp do świadczeń zdrowotnych, które ilustrują tzw. „białe plamy” [33]. W 2015 r. jedynym województwem bez „białych plam” w zakresie onkologii było województwo śląskie, a największe potrzeby istniały w województwach: mazowieckim, kujawsko-pomorskim, pomorskim, lubelskim, lubuskim, podlaskim, warmińsko-mazurskim i wielkopolskim.

Nierównomierna dostępność do radioterapii jest jednym z najważniejszych problemów onkologii w Polsce [33]. Warunki do leczenia promieniami są tylko w dużych miastach i w największych ośrodkach specjalistycznych.

Problem ten dotyczy objętego badaniem CONCORD 2 województwa podkarpackiego, a także opolskiego i warmińsko-mazurskiego, gdzie liczba aparatów na liczbę mieszkańców jest najniższa w kraju [34]. W Polsce na 1 akcelerator MV przypada 267097 osób, a na 1 aparat HDR - 874134 osób, co w porównaniu ze średnią europejską wskazuje na duże niedobory sprzętowe. Według norm europejskich do spełnienia standardów optymalnego leczenia w Polsce brakuje 47 akceleratorów MV i 18 aparatów HDR [33]. Ponadto niedobory aparaturowe powodują nadmierną eksploatację sprzętu i ich awaryjność [34, 35].

Niedoposażenie szpitali współistnieje ze zróżnicowaniem wskaźników 5-letnich przeżyć w badaniu CONCORD 2. Jak wynika z tab. IV, w województwach dolnośląskim i wielkopolskim obciążenie aparatów megawoltowych jest podobne, a wydatki per capita zbliżone, to z kolei współistnieje z wysokimi wskaźnikami przeżyć u chorych na raka okrężnicy, odbytnicy, piersi i gruczołu krokowego.

Wydaje się, że wskaźniki 5-letnich przeżyć u chorych na raka szyjki macicy mogą być efektem wcześniejszego szczególnego osobistego zaangażowania realizatorów walki z rakiem szyjki macicy $[36,37]$.

Wreszcie - wyleczalność nowotworów pozostaje w ścisłej zależności od zamożności kraju i optymalnego finansowania systemu leczenia. W kolejnych edycjach EUROCARE korelację pomiędzy wyleczalnością nowotworów i wartością produktu krajowego brutto (GDP — Gross Demostic Product) oraz wydatkami na zdrowie (TNEH Total National Expediture health) wykazali Micheli i wsp., a ostatnio Baili i wsp. $[22,23]$. Wysokie wartości TNEH w Europie Zachodniej i Centralnej korespondowały z wysokimi wskaźnikami przeżyć. Analiza danych EUROCARE 5 wykazała, że w krajach Europy Zachodniej wydatki na zdrowie były 2-3 razy większe w porównaniu z wydatkami w Europie Wschodniej. 
W Polsce niskie wskaźniki przeżyć chorych na nowotwory pozostawały $w$ relacji $z$ wydatkami na zdrowie znacznie niższymi aniżeli w krajach Europy Zachodniej. Według Leungo-Fernandeza i wsp. w 2009 roku w Polsce wydatki na leki onkologiczne stanowiły około 19\% (267 mln euro) ogółu wydatków medycznych związanych z leczeniem nowotworów i były niższe w stosunku do krajów europejskich, gdzie stanowiły około $27 \%$ wszystkich wydatków medycznych (13 $604 \mathrm{mln}$ euro) [38].

Z analizy Paolo Baili i wsp. w ramach badań EUROCARE 5 wynika, że w latach 2000-2007 wyleczalność nowotworów w Polsce była optymalna w stosunku do GDP i TNEH. W oparciu o wyniki tych badań można oczekiwać, że dalsza poprawa leczenia nowotworów w Polsce jest możliwa tylko w wyniku istotnego wzrostu finansowania, przyjmując, iż dotychczasowy standard leczenia onkologicznego będzie zachowany.

\section{Wnioski}

1. Badania CONCORD 2 potwierdzają obserwowane od dawna znaczące zróżnicowanie wyleczalności chorych na nowotwory złośliwe pomiędzy Polską a krajami Europy Zachodniej na niekorzyść Polski, a także krajów byłego bloku wschodniego. Zróżnicowanie to w szczególności dotyczy raka odbytnicy, szyjki macicy i gruczołu krokowego. Mniejsze zróżnicowanie było u chorych na raka piersi, okrężnicy i żołądka, a najmniejsze u chorych na raka płuca i jajnika oraz białaczki.

2. W Polsce, podobnie jak w innych krajach europejskich, rokowanie zależało od jednostki chorobowej. Najwyższe wskaźniki 5-letnich przeżyć były u chorych na raka gruczołu krokowego i piersi, niższe u chorych na raka okrężnicy, odbytnicy, białaczki i raka jajnika, a najniższe w raku żołądka i płuca.

3. Przeżycia analizowane w wybranych województwach Polski są zróżnicowane na korzyść woj. dolnośląskiego i wielkopolskiego w przypadku raka żołądka, jelita grubego, piersi oraz gruczołu krokowego, oraz na korzyść woj. podkarpackiego i świętokrzyskiego u chorych na raka szyjki macicy. Zróżnicowanie to współistnieje z niejednakowymi zasobami lecznictwa specjalistycznego.

4. Zróżnicowanie przeżyć chorych na nowotwory w krajach europejskich współistnieje $z$ różnym poziomem wydatków na zdrowie, od którego w dużym stopniu zależy skuteczność skriningów populacyjnych, dostępność do optymalnego leczenia bez zbędnych opóźnień, a także opieka nad chorym. Optymalne finansowanie wpływa również na zasoby kadrowe, dzięki czemu lepiej przeprowadzana jest diagnostyka i leczenie osób chorych na nowotwory.

5. W Polsce wiedza na temat struktury czynników rokowniczych w populacji i ich wpływu na wyleczalność nowotworów jest bardzo ograniczona, co utrudnia monitorowanie efektów zdrowotnych realizowanych interwencji.

\section{Podziękowanie}

Autorzy dziękują Panu Profesorowi Michelowi P. Colemanowi oraz Koleżankom i Kolegom CONCORD Working Group: CONCORD Global surveillance of cancer survival, a także Krajowemu Rejestrowi Nowotworów i Regionalnym Rejestrom Nowotworów — obecnie Wojewódzkim Biurom Rejestracji Nowotworów w Polsce, które poprzez swój udział w badaniu CONCORD 2 przyczyniły się do przeprowadzenia oceny wyleczalności nowotworów złośliwych w Polsce na podstawie danych zweryfikowanych pod względem ich jakości.

Konflikt interesów: nie zgłoszono

Artykułzostał przygotowany w ramach zadania statutowego 3/ZP.1, realizowanego w latach 2009-2015.

\section{Mgr Katarzyna Kwiatkowska}

Zakład Promocji Zdrowia i Szkolenia Podyplomowego

Narodowy Instytut Zdrowia Publicznego

- Państwowy Zakład Higieny

ul. Chocimska 24,00-791 Warszawa

e-mail:kkwiatkowska@pzh.gov.pl

Otrzymano: 14 grudnia 2015 r.

Przyjęto do druku: 2 lutego 2016 r.

\section{Piśmiennictwo}

1. www.who.int/nmh/events/un_ncd_summit2011/en (dostęp z dnia 17.07.2015)

2. www.uicc.org/ world-cancer-declaration (dostep z dnia 17.07.2015).

3. Improving Outcomes: A Strategy for Cancer. COI: Department of Health, 2011. www.gov.uk/government/publication/the-national-cancer-strategy.

3. Wojciechowska U, Didkowska J. Poprawa przeżyć chorych na nowotwory złośliwe w Polsce. Analiza pacjentów zdiagnozowanych w latach 2003-2005. Nowotwory J Oncol 2013; 63: 279-285.

4. Krzyżak M, Maślach D, Bielska-Lasota M i wsp. Breast cancer survival gap between urban and rural female population in Podlaskie voivodship, Poland, in 2001-2002. Population study. Ann Agric Environ Med 2010; 17: 277-282

5. Błaszczyk J, Jagas M, Hudziec P. Nowotwory złośliwew woj. dolnoślaskim wroku 2012. Wrocław: Dolnośląski Rejestr Nowotworów i Ministerstwo Zdrowia, 2014.

6. De Angelis R, Sant M, Coleman MP i wsp. Cancer survival in Europe 1999-2007 by country and age: results of EUROCARE-5 — a population-based study. Lancet Oncol 2014; 15: 23-34.

7. Allemani $\mathrm{C}$, Weir HK, Carreira $\mathrm{H}$ i wsp. Global surveillance of cance survival 1995-2009: analysis of individual data for 25676887 patients from 279 population-based registries in 67 countries (CONCORD 2). Lancet Oncol 2015; 385: 977-1010.

8. Wojciechowska U, Kościańska B, Nowaczyk M. International Classification of Diseases for Oncology, 3rd ed.; Międzynarodowa Klasyfikacja Chorób dla Onkologii, wyd. 3. Warszawa: Centrum Onkologii — Instytut; 2007.

9. Perme MP, Henderson R, Stare J. An approach to estimation in relative survival regression. Biostatistics 2009; 10: 136-146.

10. Hakulinen T, Pukkala E, Hakama M i wsp. Survival of cancer patients in Finland in 1953-1974. Ann Clin Res 1981; 13 Suppl 31: 1-101.

11. Miller BA, Ries LAG, Hankey BF i wsp. SEER Cancer Statistics Review. Bethesda: National Cancer Institute, 1993.

12. Koszarowski T, Gadomska H, Wronkowski Z i wsp. Epidemiologia nowotworów złośliwych w Warszawie i wybranych terenach wiejskich w latach 1963-1972. Zachorowania na nowotwory złośliwe w Polsce - prognozy. Warszawa: Instytut im. M. Skłodowskiej-Curie. Zakład Organizacji Walki z Rakiem; 1975. 
13. Capocaccia R, Gatta G, Roazzi P i wsp. The EUROCARE-3 database: methodology of data collection, standardisation, quality control and statistical analysis. Ann Oncol 2003; 14 Suppl 5: v14-27.

14. Coleman MP, Quaresma M, Berrino F i wsp. Cancer survival in five continents: a worldwide population-based study (CONCORD). Lancet Oncol 2008; 9: 730-756.

15. Coleman MP Cancer survival: global surveillance will stimulate health policy and improve equity. Lancet 2014; 383: 564-573.

16. De Angelis R, Sant M, Coleman MP i wsp. Cancer survival in Europe 1999-2007 by country and age: results of EUROCARE-5 - a population-based study. Lancet Oncol 2014; 15: 23-34.

17. Amaro J, Severo M, Vilela S i wsp. Patterns of breast cancer mortality trends in Europe. The Breast 2013; 22: 244-253.

18. Allemani $C$, Rachet $B$, Weir HK i wsp. Colorectal cancer survival in the USA and Europe: a CONCORD high-resolution study. BMJ open 2013; 3: e003055.

19. Allemani $C$, Minicozzi $P$, Berrino $F$ i wsp. Predictions of survival up to 10 years after diagnosis for European women with breast cancer in 2000-2002. Int J Cancer 2013; 132: 2400-2412.

20. Sant M, Minicozii P, Agresti R i wsp. Survival of women with cancer of breast and female genital organs: results of the EUROCARE-5 study. Eur J Cancer 2015; 51: 2191-2205.

21. Micheli A, Coebergh JW, Mugno E i wsp. European health systems and cancer care. Ann Oncol 2003; 14 Suppl 5: v41-60

22. Baili P, Di Salvo F, Marcos-Gragera R i wsp. Age and case mix-standardised survival for all cancer patients in Europe 1999-2007: Results of EUROCARE-5, a population-based study. EJC 2015; 51: 2120-2129.

23. Grodecka-Gazdecka S, Zaborek P, Didkowska J i wsp. Systemowe uwarunkowania opóźnień w diagnostyce i leczeniu kobiet chorych na raka piersi w Polsce. Nowotwory J Oncol 2014, 64: 483-490.

24. Zavoral M, Suchanek S, Zavada F i wsp. Colorectal cancer screening in Europe. World Journal of Gastroenterology 2009; 15: 5907-5915.

25. von Karsa L, Anttila A, Ronco G. Cancer Screening in the European Union. Report on the implementation of the Council Recommendation on cancer screening. First Report. Laksemburg: Komisja Europejska, 2008
26. Arbyn M, Anttila A, Jordan J. European guidelines for quality assurance in cervical cancer screening. Second edition. Luksemburg: Komisja Europejska, 2008.

27. Segnan N, Patnick J, von Karsa L. European guidelines for quality assurance in colorectal cancer screening and diagnosis. First edition. Luksemburg: Komisja Europejska, 2010.

28. Perry N, Broeders M, de Wolf C. European guidelines for quality assurance in breast cancer screening and diagnosis. First edition. Luksemburg: Komisja Europejska, 2006.

29. Kamiński MF, Reguła J, Kraszewska E i wsp. Quality indicators for colonoscopy and the risk of interval cancer. N Engl J Med 2010; 362: 1795$-1803$.

30. Spaczyński M, Karowicz-Bilińska A, Kędzia W i wsp. Koszty funkcjonowania polskiego Populacyjnego Programu Profilaktyki i Wczesnego Wykrywania Raka Szyjki Macicy w latach 2007-2009. Ginekol Pol. 2010; 81: 750-756.

31. Wasilewski P, Uczkiewicz J, Kwiatkowski K. Informacja o wynikach kontroli. Realizacja zadań "Narodowego Programu Zwalczania Chorób Nowotworowych". Warszawa: Najwyższa Izba Kontroli; 2014.

32. Kalbaczyk WP, Brzozowski S. Stan dostepności do leczniczych świadczen onkologicznych w Polsce - analiza irekomendacje. Raport przygotowany dla Polskiego Towarzystwa Onkologicznego. Warszawa: Instytut Ochrony Zdrowia, 2015.

33. Reinfuss M, Byrski E, Malicki J. Radiotherapy facilities, equipment and staffing in Poland: 2005-2011. Rep Pract Oncol Radiother 2013; 18: $159-172$

34. Dziadziuszko R. Raport na temat stanu radioterapii w Polsce na dzień 31.12.2014 r., konsultanta krajowego $w$ dziedzinie radioterapii onkologicznej. Gdańsk; 2015.

35. Malarewicz A, Rosiak J. Analiza siedmioletnich badań profilaktycznych raka szyjki macicy u kobiet zamieszkujących teren miasta Kielce. Ginekol Pol 1995; 66: 211-25.

36. Wronkowski Z, Zwierko M. Program modelowego skriningu raka piersi i raka szyjki macicy w Polsce, 1999-2000. Nowotwory J Oncol 2002; Supl. 2, 52: 7-115.

37. Luengo-Fernandez R, Leal J, Gray A i wsp. Economic burden of cancer across the European Union: a population-based cost analysis. Lancet Oncology 2013; 14: 1165-1174. 